\title{
BUAH NAGA SEBAGAI SUMBER PENDAPATAN ALTERNATIF PETANI KELAPA DI KECAMATAN TOBELO TIMUR
}

\author{
Zeth Patty*1, Ariance Y. Kastanja ${ }^{2}$, Nonice Manikome ${ }^{3}$ \\ 1,2,3Program Studi Agroteknologi, Fakultas Sains, Teknologi dan Kesehatan, Universitas Hein \\ Namotemo, Jl. Kompleks Pemerintahan Villa Vak I Tobelo, Halmahera Utara.telepon \\ 09242621669 \\ *E-mail : zethpatty4@gmail.com
}

\begin{abstract}
Low selling prices, low coconut production due to old age of coconut plants, and monoculture planting patterns are some of the factors that cause low income of coconut farmers so they live in poverty. Service activities carried out on coconut farmers in East Tobelo Sub district with the aim of training farmers to have the knowledge and skills to cultivate dragon fruit plants as intercrops among coconut plants. Problems faced by farmers include, lack of knowledge and skills in cultivating dragon fruit plants. The target to be achieved is the increasing knowledge and skills of coconut farmers in dragon fruit cultivation techniques. The methods used include counseling, training and planting dragon fruits in demonstration plot. This service program can be concluded to be able to produce expected outcomes including providing new knowledge and skills for group members while at the same time encouraging the community to seek additional income independently
\end{abstract}

Keywords: Nursery training, seedling demonstration plot, planting, dragon fruit plants

\section{Abstrak}

Harga Jual yang rendah, produksi kelapa yang rendah karena umur tanaman kelapa yang sudah tua, serta pola penanaman yang monokultur adalah beberapa faktor yang menyebabkan rendahnya pendapatan petani kelapa sehingga mereka hidup dalam kemiskinan. Kegiatan pengabdian yang dilaksanakan pada petani kelapa di Kecamatan Tobelo Timur dengan tujuan untuk melatih petani agar memiliki pengetahuan dan ketrampilan untuk membudidayakan tanaman buah naga sebagai tanaman sela di antara tanaman kelapa. Masalah yang dihadapi petani antara lain, kurangnya pengetahuan dan ketrampilan budidaya tanaman buah naga, Target yang ingin dicapai adalah semakin meningkatnya pengetahuan dan ketrampilan petani kelapa dalam teknik budidaya tanaman buah naga. Metode yang digunakan antara lain penyuluhan, pelatihan dan penanaman di kebun contoh. Program pengabdian ini dapat disimpulkan maтри menghasilkan luaran-luaran yang diharapkan termasuk memberi pengetahuan dan ketrampilan baru bagi anggota kelompok sekaligus mendorong masyarakat untuk mengupayakan tambahan pendapatan secara mandiri

Kata kunci : Pelatihan pembibitan, demplot bibit, penanaman, tanaman buah naga

\section{PENDAHULUAN}

\subsection{Latar belakang}

Tanaman kelapa (Cocos nucifera. Linn.) dalam perekonomian Indonesia merupakan salah satu komoditi strategis karena perannya yang sangat besar, baik sebagai sumber pendapatan maupun sumber bahan baku industri [1]. Data Direktorat Jenderal Perkebunan menunjukkan bahwa luas perkebunan kelapa rakyat di Maluku Utara sampai dengan tahun 2015, mencapai 217.004 Ha dengan produksi sebesar 231.571 ton [2]. Tanaman kelapa sendiri masih merupakan tanaman unggulan untuk Kabupaten Halmahera Utara dengan luas mencapai 55.435 ha dengan produksi sebesar 66.198 ton, sedangkan pada Kecamatan Tobelo Timur, tanaman kelapa masih mendominasi jenis tanaman perkebunan milik petani dengan luas mencapai $1.740 \mathrm{Ha} \mathrm{[3]}$

Kecamatan Tobelo Timur adalah salah satu kecamatan di Kabupaten Halmahera Utara, yang terdiri dari 6 desa. Umumnya petani kelapa di Kecamatan Tobelo Timur masih 
membudidayakan Kelapa Dalam yang dimiliki dengan cara tradisional, sehingga petani mengalami banyak masalah, mulai dari kualitas kopra yang dihasilkan bahkan harga jual yang diterima petani, [3]

Rendahnya kualitas kopra di daerah ini diduga sebagai salah satu penyebab rendahnya harga kopra yang dihasilkan daerah ini. Kelapa yang digunakan sebagai bahan baku kopra dinilai masih terlalu muda sehingga menghasilkan kopra yang lunak, yang rusak selama pengolahan. Selain umur buah kelapa, cara pengasapan cara pengasapan untuk mengeringkan daging kelapa sehingga kopra yang dihasilkan berwarna cokelat kehitaman [4]

Turunnya harga kopra di sejumlah daerah sentra produksi kelapa pada beberapa bulan terakhir, telah memicu berbagai persoalan sosial dan ekonomi [5]. Persoalan yang sama juga dihadapi petani kelapa di Tobelo, dimana harga kopra di daerah ini turun hingga Rp. $2.200-$ Rp.3.000 per kg. Rendahnya harga kopra telah menimbulkan banyak persoalan bagi masyarakat, terutama keluarga petani kelapa [5]

Dipilihnya Kecamatan Tobelo Timur sebagai lokasi penerapan ipteks karena sebagian masyarakatnya adalah petani kelapa dengan pola pertanaman monokultur dan tanaman kelapa yang dimiliki adalah kelapa berumur tua. Selain itu petani kelapa di Kecamatan Tobelo Timur masih membudidayakan kelapa yang dimiliki dengan cara tradisional, sehingga petani mengalami banyak masalah, termasuk masih terjerat sistem ijon dari pengusaha kopra yang memberlakukan sistem panjar (bayar dimuka), sehingga petani hanya bertindak sebagai penerima harga (price taker) karena telah meminjam uang dari tengkulak /pengusaha kopra.

Kondisi ini direspon oleh petani kelapa dengan mulai menanam tanaman sela seperti pisang dan jagung yang ditanam di antara tanaman kelapa, yang diharapkan dapat menambah pendapatan petani. Dalam perkembangannya petani kelapa di Kecamatan Tobelo Timur juga mencoba untuk mengembangkan tanaman buah naga sebagai tanaman sela, namun mengalami kesulitan karena belum mengetahui teknik budidaya tanaman buah naga. Hal ini karena tanaman buah naga adalah tanaman baru bagi mereka, dan bukan asli daerah Halmahera [6]. Masalah yang ada inilah yang menjadi alasan perlunya melaksanakan pelatihan atau pendampingan dari berbagai pihak yang dianggap memiliki kemampuan untuk melatih petani. Kegiatan ini diharapkan mampu merubah paradigma petani tentang pola pertanaman dan mendorong peningkatan pendapatan keluarga petani. Diharapkan dengan adanya kegiatan ini mampu merubah paradigma petani tentang pola pertanaman dan mendorong peningkatan pendapatan keluarga petani.

\subsection{Permasalahan Mitra}

Keinginan petani untuk menggantikan sebagian tanaman kelapa yang telah berusia tua dan tidak produktif lagi serta mengembangkan tanaman sela di antara tanaman kelapa ternyata terhambat oleh sejumlah masalah mendasar yang dirasakan oleh kelompok. Masalah tersebut antara lain :

1) Kurangnya tersedianya bibit untuk ditanam sebagai tanaman sela maupun tanaman pekarangan

2) Kurangnya pengetahuan dan ketrampilan dalam menyiapkan bibit tanaman buah naga,

3) Kurangnya pengetahuan tentang teknik budidaya tanaman buah naga,

4) Belum dimilikinya pengetahuan untuk melakukan penananam buah naga sebagai tanaman sela

1.3. Penelitian sebelumnya

Hasil penelitian sebelumnya menunjukkan bahwa Integrasi kelapa dengan tanaman lain sudah banyak dilakukan hampir di semua perkebunan rakyat kelapa. Perkebunan rakyat biasanya tidak mengembangkan model pertanaman monokultur. Tanaman kelapa ditanam di lahan tegalan, sawah dan pekarangan bersama dengan tanaman lain, baik tanaman semusim maupun tahunan [7]

Dari sisi pendapatan, penelitian Wicaksono (2018) menunjukkan bahwa 91,67\% petani responden yang mengusahakan budidaya buah naga menganggap bahwa kehidupan mereka menjadi lebih baik [8]. Wicaksono juga juga menyatakan bahwa terdapat $61,11 \%$ pedagang yang menganggap bahwa buah naga termasuk buah yang dapat disimpan lebih lama sehingga tidak merugikan petani maupun pedagang [8] 


\subsection{Lokasi dan Tempat}

\section{METODE}

Kegiatan pengabdian masyarakat ini dilaksanakan selama 8 bulan di Kecamatan Tobelo Timur, lebih khusus pada kelompok tani di Desa Mawea dan Desa Leleoto

2.2. Metode Pelaksanaan

Metode yang digunakan dalam kegiatan ini mencakup beberapa metode sebagai berikut :

1) Metode penyuluhan, digunakan untuk memperkenalkan buah naga bagi petani kelapa

2) Metode pelatihan dan demonstrasi, dilakukan dalam pelatihan perbanyakan buah naga

3) Pembuatan demplot dilakukan untuk kegiatan perbanyakan buah naga yang dilanjutkan dengan pembuatan kebun contoh

\subsection{Tahapan Kegiatan}

Tahapan kegiatan yang dilakukan untuk menyelesaikan persoalan yang dihadapi petani adalah sebagai berikut :

1) Persiapan awal.

2) Pelatihan penyiapan setek buah naga.

3) Pembuatan demplot pembibitan buah naga dari setek

4) Pembuatan kebun contoh

\subsection{Partisipasi Mitra}

Partisipasi yang diharapkan dalam pelaksanaan program sebagai berikut :

1) Mendukung dan bekerjasama dengan pelaksana untuk menyukseskan pelaksanaan kegiatan.

2) Menyediakan lahan untuk lokasi pembuatan Demplot Pembibitan;

3) Menyediakan lahan untuk kebun contoh

4) Memanfaatkan dan menjaga secara baik kebun contoh dan sarana produksi yang disediakan untuk keberlangsungan kegiatan kelompok.

\subsection{Evaluasi}

Evaluasi dilakukan pada setiap tahap kegiatan, baik kegiatan penyuluhan, kegiatan pelatihan maupun pembuatan demplot pembibitan dan kebun contoh. Evaluasi yang dilakukan mencakup ketrampilan perbanyakan bibit yang dilatihkan kepada petani, Keberhasilan kegiatan pembibitan, serta keberhasilan pertumbuhan bibit buah di kebun contoh.

Evaluasi dilakukan dengan pengisian daftar pertanyaan maupun dengan melakukan pengamatan atas variabel yang telah ditentukan. Hasil pelatihan maupun hasil pembibitan pada demplot dan kebun buah naga diarahkan untuk dapat mengukur secara kuantitatif hasil kegiatan. Dengan demikian dapat dilihat indikator akhir pencapaian target dari kegiatan pengabdian ini baik secara kuantitatif dan kualitatif hasil dari kegiatan ini.

\subsection{Tahap persiapan}

\section{HASIL DAN PEMBAHASAN}

Tahap persiapan diawali dengan melakukan konsolidasi tim pelaksanan pengabdian dengan kelompok petani, dilanjutkan dengan pemaparan dan sosialisasi program kegiatan. Tim kemudian bersama-sama dengan kelompok menyusun jadwal kegiatan serta membicarakan berbagai kebutuhan di lapangan termasuk lahan untuk membuat kebun contoh. Secara internal tim juga mulai menyiapkan bahan dan peralatan yang dibutuhkan termasuk juga materi-materi yang diperlukan dalam kegiatan penyuluhan / pelatihan. Untuk keperluan evaluasi hasil kegiatan, dipersiapkan kuisioner yang diisi oleh peserta.

\subsection{Pelatihan Perbanyakan Bibit Buah Naga}

Pelatihan diawali dengan memperkenalkan anggota tim yang berasal dari Program Studi Agroteknologi Fakultas Sains, Teknologi dan Kesehatan Universitas Hein Namotemo yang ikut bersama dalam Tim. Setelah itu disampaikan penjelasan tujuan dan manfaat dari pelaksanaan pelatihan dimaksud, yang dilanjutkan dengan pemutaran beberapa video tentang tanaman buah naga dan cara mengawinkan buah naga. 
Kegiatan dilanjutkan dengan penyampaian materi oleh pemateri utama tentang cara memperbanyak buah naga dengan menggunakan setek. Pada sesi ini pemateri menjelaskan langkah-langkah untuk menyiapkan bibit buah naga secara vegetatif, kemudian dilakukan demonstrasi yang diikuti dengan pembuatan bibit oleh anggota kelompok. Langkah-langkah adalah sebagaimana disarankan yakni sebagai berikut : [9],

a) Setek diambil dari cabang buah buah naga yang yang pernah berbuah 3-4 kali, dengan diameter setidaknya $8 \mathrm{~cm}$, keras, tua, berwarna hijau kelabu dan sehat.

b) Potong-potong batang calon bibit dengan panjang sekitar 20-30 cm, setidaknya memiliki setidaknya 4 mata tunas.

c) Biarkan batang setek yang telah dipotong- hingga getahnya mongering, bila langsung ditanam getah yang masih basah bisa menyebabkan busuk batang.

d) Siapkan polybag yang telah diisi dengan media tanam, kemudian tancapkan bagian setek yang runcing ke dalam media tanam sedalam $5 \mathrm{~cm}$

e) Berikan naungan atau sungkup untuk melindungi setek tersebut. Lakukan penyiraman sebanyak 2-3 hari sekali.

f) Setelah 3 minggu, tunas pertama mulai tumbuh dan naungan atau sungkup harus dibuka agar bibit mendapatkan cahaya matahari penuh.

g) Pemeliharaan bibit biasanya berlangsung hingga 3 bulan. Pada umur ini tinggi bibit berkisar $50-80 \mathrm{~cm}$.
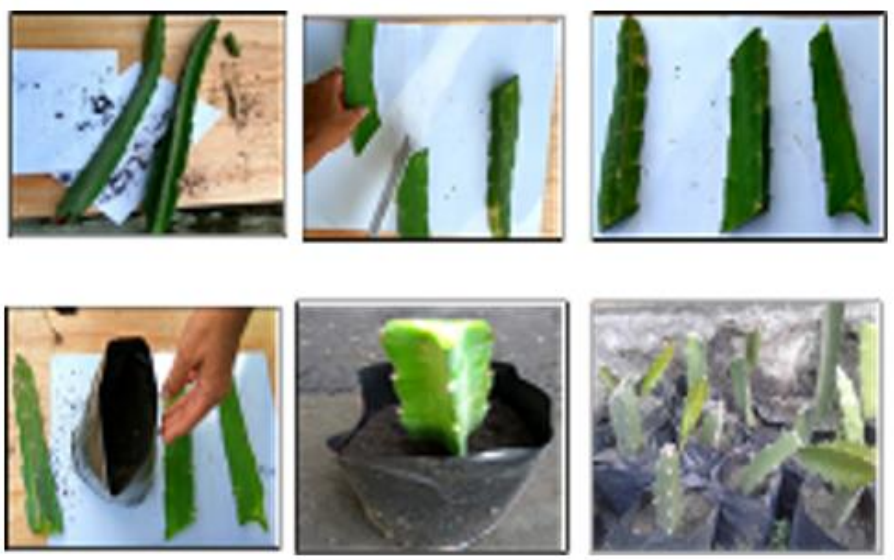

Gambar 1. Tahapan Membuat Setek Buah

Pada sesi pelatihan perbanyakan bibit buah naga, dilakukan evaluasi dengan melakukan pengamatan terhadap anggota kelompok yang sedang melakukan praktek pembuatan bibit buah naga. Variabel yang diamati antara lain ukuran diameter calon bibit yang dipilih, ukuran panjang bibit yang dipotong, campuran bahan media tanam, cara mengisi polibag, posisi mata tunas saat ditanam dan jumlah mata tunas yang terlihat di atas tanah. Hasil evaluasi atas keberhasil kegiatan pelatihan dapat dilihat pada gambar di bawah ini.

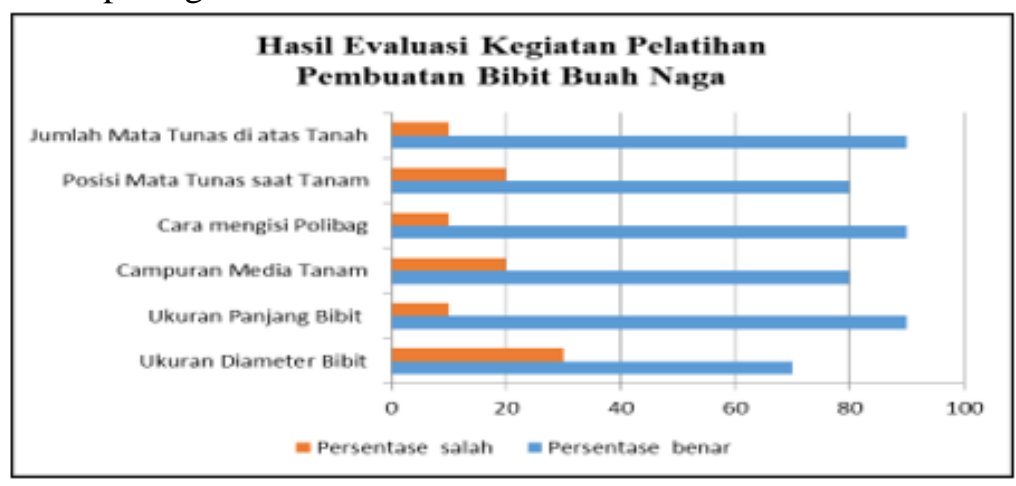

Gambar 2. Hasil Evaluasi Kegiatan pelatihan Pembuatan Bibit Buah Naga dengan setek 


\subsection{Demplot Pembibitan Tanaman Buah Naga}

Demplot pembibitan dibuat bersama kelompok di lokasi yang ditentukan oleh anggota yang dianggap dekat dengan lokasi kebun contoh. Setelah 3-4 minggu bibit mulai mengeluarkan mata tunas. Setelah berumur 3 bulan dilokasi pembibitan, dan panjang tunas mencapai $50-70 \mathrm{~cm}$, bibit siap untuk dipindahkan ke lokasi kebun contoh.
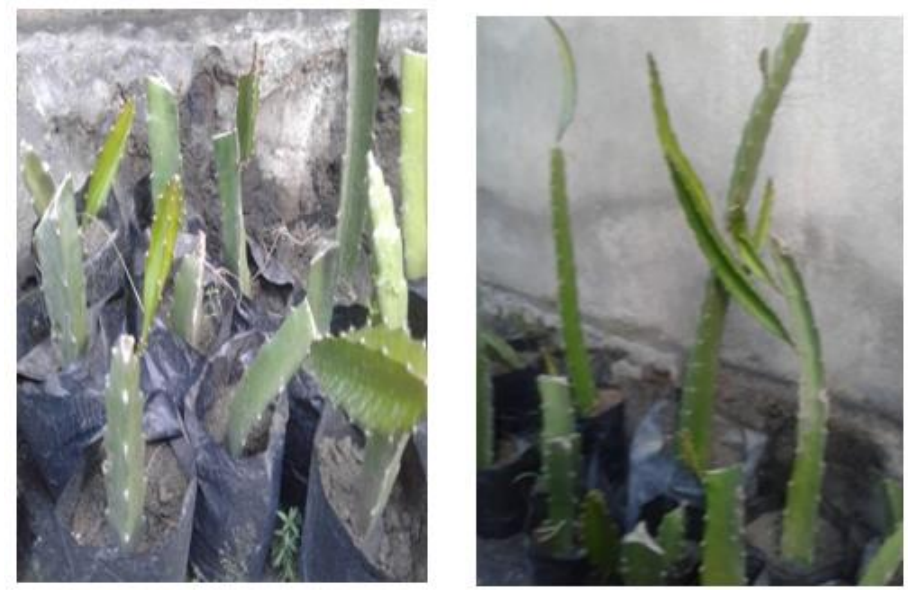

Gambar 3. Bibit buah naga yang berumur 3 minggu dan 3 bulan

\subsection{Membuat Kebun Contoh Tanaman Buah Naga}

Pembuatan kebun contoh diawali dengan pembuatan tiang panjat yang dibuat setinggi 2 meter [9], dan diberi silangan kayu di bagian atas yang menjadi tempat merambat tanaman buah naga. Tiang panjat diperlukan untuk menopang batang tanaman agar tidak mudah roboh [9].

Penanaman buah naga dilakukan dengan mempraktekkan model penanaman lorong (allei cropping) di antara tanaman kelapa. Model penanaman lorong (allei cropping) sendiri adalah suatu cara pemeliharaan lahan dengan menanam tanaman lorong/pagar, yang dari tanaman tersebut kita tidak hanya mengurangi resiko erosi melainkan kita juga memperoleh manfaat lain dari tanaman lorong tersebut, misalnya mulsanya (sisa-sisa tanaman yang sangat cepat membusuk dan menjadi penyubur lahan), bahkan mungkin tanaman lorong dapat digunakan sebagai makanan ternak. Budidaya lorong adalah upaya pemanfaatan lahan dengan tanaman tahunan dan tanaman semusim. Tanaman semusim ditanam di lorong tanaman pagar [10]

Tiang panjat ditanam dengan jarak $3 \mathrm{~m} \times 3 \mathrm{~m}$ menyesuaikan dengan jarak tanam yang dianjurkan yakni jarak tiang dalam satu baris 2,5 meter sedangkan jarak antar baris 3 meter, [10][7]-[8], pada lahan kelapa yang memiliki jarak tanam $7 \mathrm{~m} \times 7 \mathrm{~m}$ sampai $9 \mathrm{~m} \times 7 \mathrm{~m}$. Dalam pembuatan kebun contoh ini, dilakukan penanaman 50 tiang di masing-masing lokasi sebagai lanjaran buah naga.

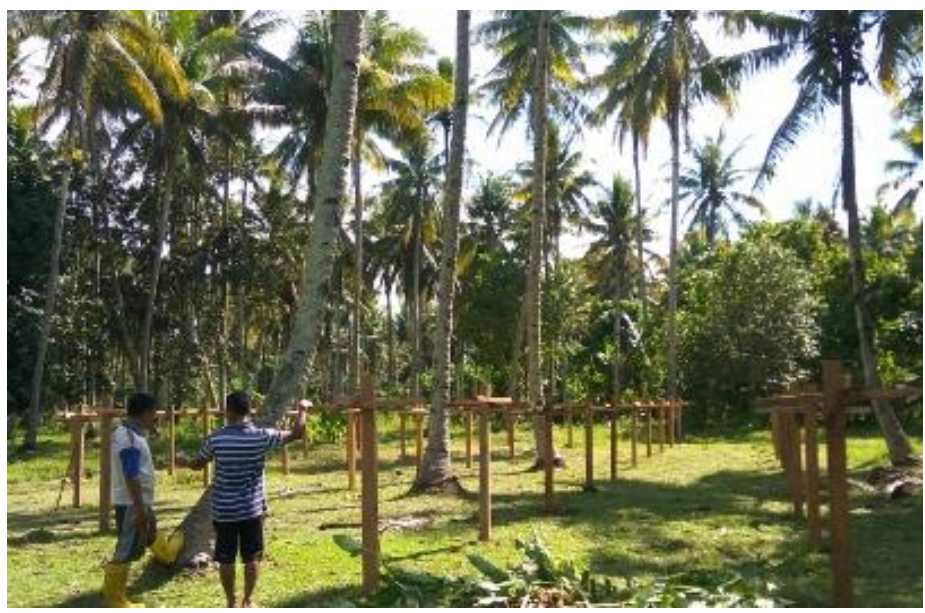

Gambar 4. Tiang Panjat yang telah ditanam di kebun contoh 
Setelah pemasangan tiang panjat kemudian bibit yang ditanam di lokasi tersebut. Bibit buah naga ditanam sesuai anjuran yakni dengan jarak $10 \mathrm{~cm}$ dari tiang panjat mengikuti panduan cara tanam buah naga [9]. Kegiatan penanaman ini dilakukan selama 2 hari. Hari pertama dilakukan persiapan tiang dan pemasangan tiang di lokasi, sedangkan pada hari kedua dilakukan penanaman bibit buah naga pada tiang yang telah disiapkan.

Tanaman buah naga berumur panjang dengan siklus produktif bisa mencapai 15-20 tahun. Budidaya buah naga mulai berbuah untuk pertama kali pada bulan ke 10 hingga 12 terhitung setelah tanam. Namun apabila ukuran bibit tanamannya lebih kecil, panen pertamanya bisa mencapai 10 - 12 bulan setelah tanam [9], ada juga yang panen setelah berumur $18-24$ bulan setelah panen [11]

Evaluasi Terhadap keberhasilan demplot pembibitan dan kebun contoh dilakukan dengan melakukan pengamatan. Keberhasilan pada demplot pembibitan diukur dengan mengamati jumlah tanaman yang mengeluarkan tunas setelah 3 minggu dan setelah berumur 3 bulan, sebelum dipindahkan ke lapangan. Bibit yang tidak mengeluarkan tunas sampai waktu yang ditentukan dianggap gagal. Keberhasilan tanaman di kebun contoh, diukur dengan mengamati jumlah tanaman yang dipindahkan ke lokasi dan jumlah bibit yang bertahan hidup setelah 2 minggu di lapangan.

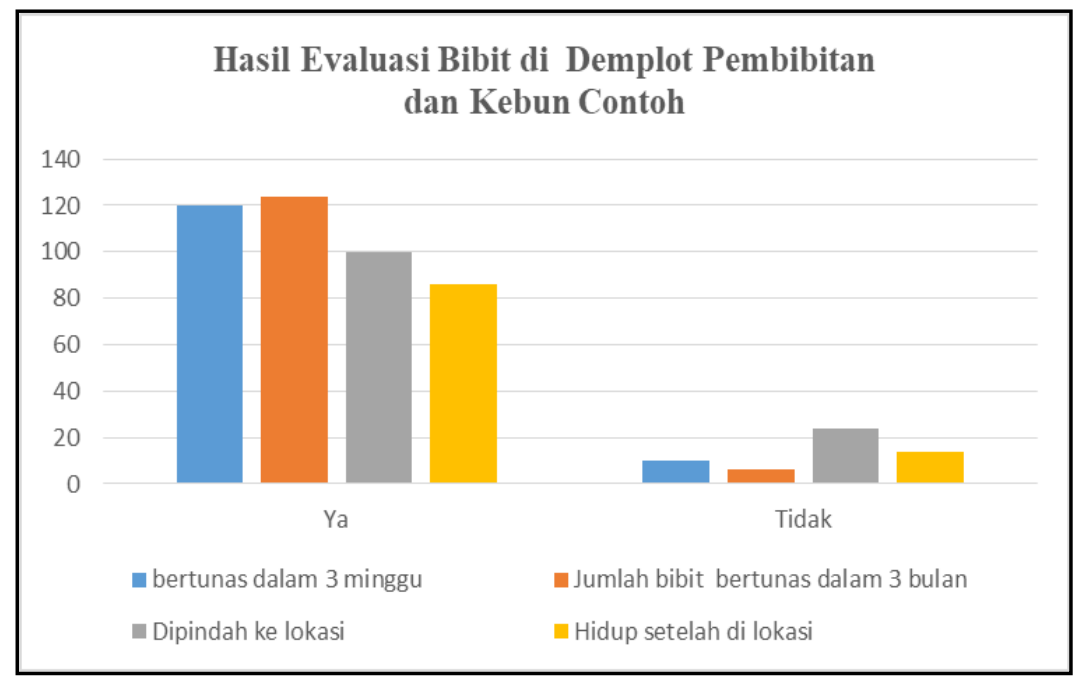

Gambar 5. Hasil Evaluasi Demplot dan Kebun Contoh

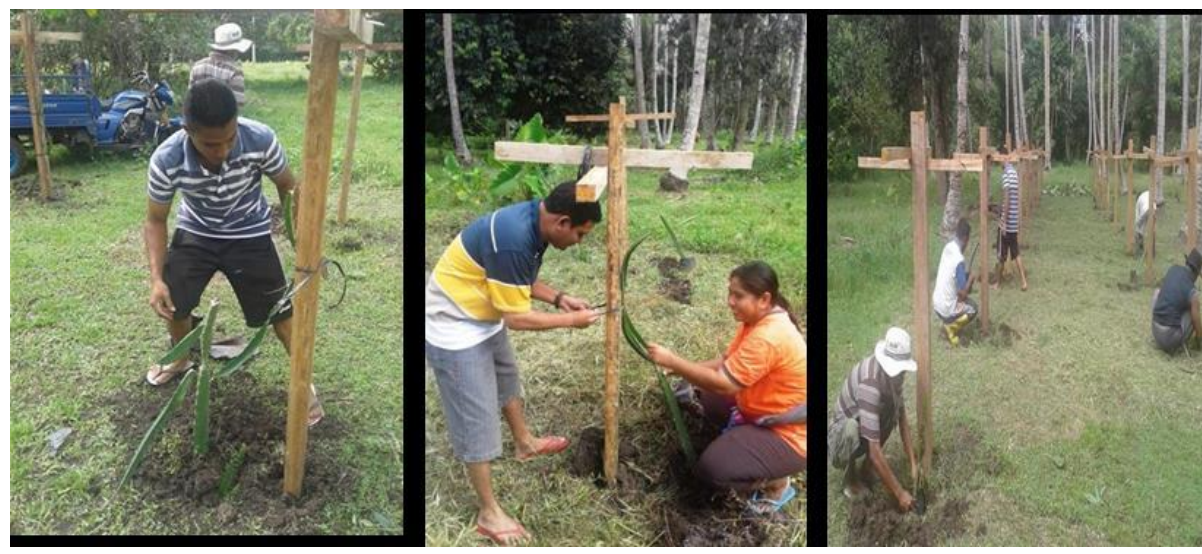

Gambar 6. Penananam Bibit Buah Naga di kebun Contoh

\subsection{Proyeksi Pendapatan}

Materi tentang analisa usahatani tanaman buah naga disampaikan oleh dosen ekonomi pertanian pada Fakultas Sains Teknologi dan Kesehatan, Universitas Hein Namotemo. Dalam kesempatan ini pemateri mengajak petani untuk membudidayakan tanaman buah sebagai tanaman sela pada kebun kelapa milik petani, serta mencoba menjelaskan pendapatan yang dapat diterima petani sebagai tambahan pendapatan. Pendapatan yang dimaksudkan adalah pendapatan kotor 
yang dapat diterima petani dari hasil penjualan buah naga. Pendapatan kotor atau penerimaan total adalah nilai produksi komoditas pertanian secara keseluruhan sebelum dikurangi biaya produksi [12]

Dalam simulasi, harga jual yang digunakan adalah harga riil di kota Tobelo yang dapat mencapai Rp.20.000 - Rp.40.000 per kilogramnya. Harga ini lebih tinggi dibanding beberapa daerah lain seperti di Makassar yang hanya Rp.29.000 per kilogram [13]. Jumlah tanaman yang digunakan dalam simulasi adalah jumlah tanaman buah naga yang hidup dan dimiliki kelompok petani dari hasil penanaman di kebun contoh. Sehingga untuk menghitung tambahan pendapatan yang bisa diperoleh petani kelapa yang memiliki 86 tiang buah naga dengan asumsi hasil produksi $1 \mathrm{~kg}$ per tiang, maka petani berpeluang memperoleh Rp.1.720.000 sampai Rp.3.440.000 tiap kali panen. Kondisi lahan yang sangat subur dan curah hujan sepanjang tahun, membuat tanaman buah naga di Halmahera Utara dapat berbuah setiap bulannya, sehingga petani dapat memperoleh jumlah tambahan pendapatan setiap bulan atau setidaknya per 2 bulan. Tabel berikut adalah proyeksi pendapatan buah naga jika dijual di pasar Tobelo.

Tabel.1. Proyeksi Produksi dan Pendapatan Buah Naga Sesuai Harga Jual di Pasar Kota Tobelo

\begin{tabular}{lcccc}
\hline No & $\begin{array}{c}\text { Jumlah } \\
\text { Tanaman } \\
\text { hidup }\end{array}$ & $\begin{array}{c}\text { Produksi } \\
(1 \mathrm{~kg} / \text { pohon })\end{array}$ & $\begin{array}{c}\text { Harga Jual } \\
\text { (Rp) }\end{array}$ & $\begin{array}{c}\text { Pendapatan } \\
\text { (Rp) }\end{array}$ \\
\hline 1 & 86 & $86 \mathrm{~kg}$ & 20.000 & 1.720 .000 \\
2 & 86 & $86 \mathrm{~kg}$ & 35.000 & 3.010 .000 \\
3 & 86 & $86 \mathrm{~kg}$ & 40.000 & 3.440 .000 \\
\hline
\end{tabular}

\section{KESIMPULAN}

1. Pelatihan perbanyakan buah naga dengan setek telah meningkatkan pengetahuan dan ketrampilan petani dalam melakukan perbanyakan bibit buah naga, ditunjukkan dengan adanya perubahan pengetahuan dan ketrampilan setelah mengikuti pelatihan.

2. Petani kelapa yang mengikut pelatihan telah memiliki ketrampilan untuk menghasilkan bibit buah naga secara mandiri.

3. Penanaman bibit buah naga di kebun contoh menunjukkan bahwa tanaman buah naga jika ditanam sebagai tanaman sela akan cukup berhasil bagi petani kelapa.

4. Petani kelapa yang menanam buah naga dapat menghasilkan tambahan pendapatan sekitar Rp.1.720.000 - Rp.3.440.000 per 2 bulan.

\section{UCAPAN TERIMA KASIH}

Penulis menyampaikan terima kasih kepada Kementeriaan Riset Teknologi dan Pendidikan Tinggi (Ristekdikti) yang telah memberikan dukungan secara finansial melalui skema Iptek bagi Masyarakat (IbM), sehingga terlaksananya kegiatan pengabdian ini.

\section{DAFTAR PUSTAKA}

[1] Patty Zeth, "Analisis produktivitas dan nilai tambah kelapa rakyat," Agroforestri, vol. 6, no. 2, pp. 153-159, 2011.

[2] Anonimous, Statistik Perkebunan Indonesia, Kelapa 2015 - 2017. Jakarta, 2016.

[3] BPS Halut, "Kecamatan Tobelo Timur Dalam Angka," Tobelo, 82050.1807, 2018.

[4] Khori Arianti, "Mengurai Kemacetan Ekspor Kopra Maluku Utara," 2017. .

[5] Republika.co.id, "Harga Kopra Anjlok , Petani di Halmahera Utara," 2018. [Online]. Available: https://www.republika.co.id/berita/nasional/daerah/18/11/21/piiy7q409-hargakopra-anjlok-petani-di-halmahera-utara-boikot-jalan. [Accessed: 25-Mar-2019].

[6] Alamtani, "Panduan Teknis Budidaya Buah Naga," 2019. [Online]. Available: https://alamtani.com/budidaya-buah-naga/. [Accessed: 04-Mar-2019]. 
[7] S. W. Abidin, "Tumpang Sari Pada Produksi Benih Kelapa Dalam,” 2016.

[8] Wicaksono, "Potensi dan Preferensi Usaha Budidaya Buah Naga Sebagai Upaya Meningkatkan Pendapatan Masyarakat Dalam Perspektif Ekonomi Islam," Unversitas Islam Negeri Raden Intan, 2018.

[9] C. Tanam, "Budidaya dan Cara Menanam Buah Naga Agar Cepat Berbuah," 2019. [Online]. Available: https://caratanam.com/cara-menanam-buah-naga/. [Accessed: 01-Mar-2019].

[10] Rahman Aritonang, "Budidaya Lorong," 2012. [Online]. Available: http://www.stppgowa.ac.id/informasi/artikel-ilmiah/255-budidaya-lorong-suatu-alternatifpertanian-berkelanjutan.htm. [Accessed: 01-Mar-2019].

[11] A. P. Soedarya, Agrisbisnis Buah Naga. Bandung: CV Pustaka Grafika, 2013.

[12] I. C. K. Putri, "Pendapatan, Analisis Kakao, Petani Kabupaten, D I Moutong, Parigi," Jurnal EMBA, vol. 1, no. 4, pp. 2195-2205, 2013.

[13] Anonimous, “Anjloknya Harga Buah Naga Di Jawa Tak Berpengaruh ke makassar," 2019. [Online]. Available: http://sulsel.inikata.com/index.php/anjloknya-harga-buah-naga-di-jawatak-berpengaruh-ke-makassar/. [Accessed: 01-Apr-2019]. 